\title{
Induced resistance by Bacillus subtilis on oil palm seedling infected by Ganoderma boninense
}

\author{
FIFI PUSPITA ${ }^{1,2, \bullet}$, HADIWIYONO ${ }^{1}$, SUSILO HAMBEG POROMORTO ${ }^{1}$, DEWI INDRIYANI ROSLIM ${ }^{2}$ \\ ${ }^{1}$ Progam of Agricultural Sciences, Graduate School, Universitas Sebelas Maret. Jl. Ir. Sutami 36A,. Surakarta 57 126, Central Java, Indonesia. \\ Tel./fax.: +62-271-637457, `email: fipspt@gmail.com \\ ${ }^{1}$ Department of Agrotechnology, Faculty of Agriculture, Universitas Riau. Jl. H.R. Soebrantas Km. 12,5, Kampus Bina Widya, Simpang Baru, Pekanbaru \\ 28293, Riau, Indonesia
}

Manuscript received: 6 August 2019. Revision accepted: 2 December 2019.

\begin{abstract}
Puspita F, Hadiwiyono, Poromorto SH, Roslim DI. 2020. Induced resistance by Bacillus subtilis on Ganoderma boninense infected oil palm seedling. Biodiversitas 21: 28-33. Basal Stem Rot (BSR) caused by Ganoderma boninense Pat is the most important disease in oil palm plantations. The use of biological resistance inducer is a promising alternative disease-control. The research evaluated the potential and mechanism of endophytic Bacillus subtilis as resistance inducer agent of oil palm seedlings to infection of $G$. boninense. The Experiment was carried out using a completely randomized design consisting of 4 treatments and 3 replications namely of endophytic $B$. subtilis with four inoculum densities $\left(0,10^{11}, 10^{12}\right.$, and $\left.10^{13} \mathrm{cfu} . \mathrm{mL}^{-1}\right)$ on oil palm before inoculation of $G$. boninense. The observation variables were incubation period, disease intensity, growth and concentration of salicylic acid in leaf extract of oil palm seedlings. In addition, the ability of $B$. subtilis to produce IAA in liquid Pikovskaya medium enriched by tryptophan was assayed. The results showed that $B$. subtilis was potential as biological resistance inducer agents of oil palm seedlings to infection of $G$. boninense. The induced resistance was related to increasing growth, salicylic acid in leaf the seedlings and the capability was assayed to produce IAA.
\end{abstract}

Keywords: Bacillus subtilis, Ganoderma boninense, growth-promoting, induce resistance, oil palm

\section{INTRODUCTION}

Basal Stem Rot (BSR) caused by Ganoderma boninense Pat is the main disease in plantation of oil palm (Elaeis guineensis Jacq) in Indonesia, including in Riau Province. The fungi can infect oil palm in all of stages, starting from seedlings to old plants (Priwiratama et al 2014). The disease intensity will increase and can reach $40 \%$ on the second and third generation of oil palm plantation. In early infection, BSR can cause the end of oil palm production and reduce the weight of fresh fruit bunches (Susanto et al. 2005). Further infection, BSR can kill more than $80 \%$ of oil palm plants (Abdul Razak et al. 2004). There are many efforts to control the disease, such as using tolerance varieties. Basal stem rot has been controlled by using tolerance varieties, synthetic chemical fungicides, technical cultures, and biological control However, the techniques have not been success (Prasetyo et al. 2008).

BSR is difficult to control. Development of special disease control such as biological control is urgently needed. The advantages of using endophytic Bacillus as a biological control agent are that they can grow, proliferate and spread in plant tissue, stimulate the growth of plant, induce plant resistance by producing antibiotics and secondary metabolites (Zhao et al. 2015). Endophytic Bacillus, an inducer resistance agent, is a promising biological control agent to be developed to control the disease. Endophytic B. subtilis has been isolated from the oil palms. The use of endophytic bacteria isolated from oil palm root to control G.boninense has been conducted in vitro. The isolates are antagonistic to G. boninense and effectively inhibit the fungi at $50-55 \%$. The ability of the bacteria to suppress the growth of G. boninense with a range from 8.13-49.38\% has been reported (Nasahi et al. 2016). The bacteria could contribute to the growth of plants by increasing the leaf number and plant height in cocoa seedlings aged 3 months (Leite et al. (2013). The potency of $B$. subtilis as a resistant inducer agent in oil palm plantation has not been studied well. Therefore, the purpose of the study is to evaluate the capability of endophytic Bacillus isolated from the oil palm tissue to systemically induce the resistance of oil palm seedlings against $G$. boninense in the main seedling.

\section{MATERIALS AND METHODS}

\section{Study area}

This research was conducted in Plant Disease Laboratory, Faculty of Agriculture and Biochemistry Laboratory, Faculty of Science, Universitas Riau, Pekanbaru, Indonesia from April 2016 to December 2017.

\section{Procedures}

The study in vitro was conducted in which it measured the concentration of salicylic acid in leaf extracts including the preparation of endophytic Bacillus isolates. The pure Bacillus endophytes used were re-isolated in the sterilized Nutrient Agar (NA) medium with a scratch method. One 
isolate of endophytic Bacillus was scratched on the NA media surface in a petri dish than it was covered by plastic wrap. Next, the isolate was put inside $15 \mathrm{~cm} \times 20 \mathrm{~cm}$ polyethylene plastic and the isolate was kept inside the incubated cool box for 48 hours. Bacillus was then resuspended in the sterile aquadest in a one-liter beaker glass. The suspension of Bacillus bacteria inside the glass beaker was diluted starting from $10^{-9}$ dilution to $10^{-11}$ dilution. The dilution level used as treatment was $10^{-9}-10^{-11}$. A total of 1 $\mathrm{mL}$ suspension of endophytic $B$. subtilis at $10^{-9}-10^{-11}$ dilution was dropped into the petri dish and then liquid NA media was added. The petri dishes were shaken to right and left to get the suspension mixed with the NA. A few moments later, it became a solid medium. After being incubated for 24 hours, the colony calculation was conducted.

\section{Inoculum preparation of Ganoderma boninense}

The growing medium used as an inoculum source was a palm oil bunch which was cut into the size of $5 \mathrm{~cm} \times 5 \mathrm{~cm}$ x $2 \mathrm{~cm}$. An oil palm bunch that had been cut was soaked into sterile aquadest for 24 hours and drained until no dripping water. Then, it was put into a $15 \mathrm{~cm} \mathrm{x} 20 \mathrm{~cm}$ polypropylene plastic. The plastic was connected to a 2 $\mathrm{cm}$-long pipe covered with cotton and aluminum foil, then sterilized in an autoclave at a pressure of $15 \mathrm{psi}$ and a temperature of $121{ }^{\circ} \mathrm{C}$ for 15 minutes. After it was cold, it was transferred into the Laminar Air Flow Cabinet to perform infestation with inoculum. G. boninense inoculum infestation was performed on the top of the oil palm bunch. The inoculum was in the form of a piece of $0.5 \mathrm{~cm}$ diameter pathogenic cut on PDA media which had been 14 days old. The medium was incubated for 4 weeks at room temperature, and then it was ready to be used as a source of the initial Inoculum $G$. boninense. The medium was incubated for four months at room temperature, and then it was prepared to be used as the initial $G$. boninense inoculum source.

\section{Inoculation of Ganoderma boninense}

The oil palm seedlings used in this study were a variety of Topaz 3 (Dura Deli x Psifera Ekona) having criteria at $\pm 5 \mathrm{cmlong}$ of radicle and $\pm 3 \mathrm{cmlong}$ of plumule. The selected oil palm seedlings were then soaked for 5 minutes in the suspension of endophytic Bacillus according to the treatment. After the oil palm seedlings were one month old, the seedlings were inoculated with $G$. boninense. The inoculation of oil palm seedlings with fungi $G$. boninense was done by planting a wood substrate with a size of $5 \mathrm{~cm}$ x $5 \mathrm{~cm} \times 2 \mathrm{~cm}$ in the planting medium, approximately $2 \mathrm{~cm}$ from the stem of the seedlings. Inoculation was done in 2 weeks after the seedlings removal.

\section{Analysis of salicylic acid levels}

The analysis of salicylic acid using the extraction method was conducted based on the compound analysis of salicylic acid following the method by Keen et al. (1971). The study was conducted experimentally using the Completely Randomized Design consisting of four treatments and five repeats to obtain 20 experimental units. The treatment was with the concentration of Bacillus subtilis namely: B0: without $B$. subtilis endophyte, B1: with $B$. subtilis endophyte of $3 \times 10^{11} \mathrm{cfu} \mathrm{mL-}^{1}$, B2: with $B$. subtilis endophyte of $3 \times 10^{12} \mathrm{cfu} \mathrm{mL}^{-1}$, B3: with B. subtilis endophyte of $3 \times 10^{13} \mathrm{cfu} \mathrm{mL}^{-1}$.

\section{Inducing resistance of oil palm seedlings with endophytic Bacillus}

The inducing resistance of oil palm seedlings was conducted by watering around the seedlings with $35 \mathrm{~mL}$ of the suspension of $B$. subtilis as intended by the treatment. The inducing resistance was carried out 8 weeks after planting (oil palm seedlings aged 2 months). Then, the inoculation of $B$. subtilis was applicated on 1 month after the first application.

\section{Observation}

Incubation period

Incubation Period was conducted right after the symptoms of the leaf appeared for the first time and when the color of leaf started to become pale green (chlorosis) or yellowish starting from the edges to the middle of the leaf.

\section{Disease intensity}

Observation of disease intensity of BSR on oil palm seedlings used the scoring based on CIBA-Geigy (1997) as shown below:

$\begin{array}{cl}\begin{array}{cl}\text { score } \\ 0\end{array} & \text { Notes } \\ 1 & \text { Healthy or Normal Leaf } \\ 2 & \text { Chlorosis Leaf (Yellowish Leaf) } \\ 3 & \text { All leaves turned to necrosis } \\ 4 & \text { Dead plants }\end{array}$

The Disease Intensity (DI) was calculated according to Sudantha et al. (1993):

$$
D I=\frac{\sum\left(n_{i} \mathrm{xv}_{\mathrm{i}}\right)}{Z \mathrm{x} N} \times 100 \%
$$

Where:

DI : Diseases intensity

$\mathrm{n}$ : Number of seedling with the same score

$\mathrm{v}$ : Disease scoring on seedling

$\mathrm{Z}$ : Hight scoring

$\mathrm{N}$ : Total number of seedling

\section{Assay of salicylic acid in leaf extract}

The analysis of salicylic acid using the extraction method was conducted based on the compound analysis of salicylic acid following the method by Keen et al. (1971). The study was conducted experimentally using the Completely Randomized Design consisting of four treatments and five replication so it was obtained 20 treatment units. The treatment was the concentration of $B$. subtilis which are: $\mathrm{B} 0=$ without $B$. subtilis, $\mathrm{B} 1=$ with $B$. subtilis $10^{11}$ cfu mL- ${ }^{1}, \mathrm{~B} 2=$ with $B$. subtilis $10^{12} \mathrm{cfu} \mathrm{mL}^{-1}$,

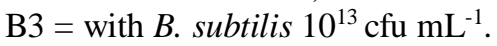

The assay of the salicylic acid in leaf was done at the end of the research. The extraction was applied to the part of the oil palm seedlings from each treatment. The first step 
was to weigh $5 \mathrm{~g}$ of leaves and then they were pulverized. The second step was the inoculation addition of $50 \mathrm{~mL}$ ethanol $70 \%$ which had been neutralized with $\mathrm{NaOH} 0.1 \mathrm{~N}$ in the pulverized leaves. The extract was homogenized for 15 minutes using a shaker and filtered using a $0.45 \mu \mathrm{m}$ filter paper. The supernatant with the titration of $\mathrm{NaOH} 0.1 \mathrm{~N}$ used a phenolphthalein indicator to form a pink color. The titration volume was $1 \mathrm{~mL} \mathrm{NaOH} 0.1 \mathrm{~N}$ which was equivalent to $13.81 \mathrm{mg}$ or 0.01381 grams of salicylic acid. The calculation of salicylic acid concentration was using the formula below:

salicylic acid concentration $=\frac{V x N x 0,01381 g r \times 100 \%}{B}$

\section{IAA assay}

Bacillus subtilis isolates were grown on a medium containing NB (nutrient broth) medium which had been added with tryptophan $1 \mathrm{~g} \mathrm{~L}^{-1}$ and then incubated for 24 hours. The bacterial culture was then centrifuged at 3000 rpm for 20 minutes. A total of $1 \mathrm{~mL}$ of the supernatant was added with $2 \mathrm{~mL}$ of Salkowski's reagent $(0.5 \mathrm{M} \mathrm{FeCl} 3$ and $70 \%$ perchloric acid. The mixture then incubated in a dark place for 30 minutes. Color changes from yellow to reddish show positive results. Absorbance was measured using a spectrophotometer at a wavelength of $535 \mathrm{~nm}$. IAA concentration was determined based on the IAA standard curve equation.

\section{Data analysis}

The test results of induced systemic resistance and plant growth-promoting agent were statistically analyzed by Analysis of Variance (ANOVA) and continued with Honestly Significant Difference (HSD) test at level of 5\%.

\section{RESULTS AND DISCUSSION}

\section{Effects of Bacillus subtilis to incubation period, disease} intensity and salicylic acid concentration

The observation result of incubation period, disease intensity, and salicylic acid concentration in the leaf extract of oil palm seedling showed that the treatments affected significantly to all of the variables. The average incubation period and disease intensity analyzed by HSD test at the level of $5 \%$ can be seen in Table 1 . Table 1 shows that the inoculation of $B$. subtilis on the density of $10^{11}$ dan $10^{12}$ cfumL $^{-1}$ caused the slowest initial symptom compared to the other treatment with the $0 \%$ disease intensity and the concentration of $0.38 \%$ salicylic acid.

\section{Bacillus subtilis from the oil palm leaf as the growth- promoting bacteria on oil palm seedlings}

The observation result of the oil palm seedling growth with the inoculation of $B$. subtilis in the oil palm seedlings showed that there was no significant influence after the analysis of variance at the level of 5\%. The average growth of oil palm seedlings and HSD results analysis at a 5\% level are presented in Table 2.

Table 1. Effects of Bacillus subtilis to incubation period, the disease intensity of BSR and salicylic acid assay of leaf extract oil palm seedlings inoculated by Ganoderma boninense.

\begin{tabular}{lccc}
\hline $\begin{array}{c}\text { Bacillus } \\
\text { subtilis } \\
\text { (cfu } \mathbf{~ m L}^{-1} \text { ) }\end{array}$ & $\begin{array}{c}\text { Incubation } \\
\text { period } \\
\text { (days) }\end{array}$ & $\begin{array}{c}\text { Disease } \\
\text { intensity } \\
(\%)\end{array}$ & $\begin{array}{c}\text { Concentration } \\
\text { of salicylic } \\
\text { acid }(\%)\end{array}$ \\
\hline No B. subtilis & $91.33 \mathrm{~b}$ & $7.29 \mathrm{a}$ & $0.33 \mathrm{~b}$ \\
$10^{11}$ & $110.00 \mathrm{a}$ & $0.00 \mathrm{~b}$ & $0.38 \mathrm{a}$ \\
$10^{12}$ & $110.00 \mathrm{a}$ & $0.00 \mathrm{~b}$ & $0.37 \mathrm{a}$ \\
$10^{13}$ & $96.42 \mathrm{~b}$ & $6.25 \mathrm{a}$ & $0.36 \mathrm{a}$ \\
\hline
\end{tabular}

Note: The average followed by the same lowercase letters indicate no significant result according to HSD test at the level 5\% based on the data transformed with $\sqrt{Y}+0.5$.

Table 3. The increasing seed height, stem diameter, and root volume after the inoculation of Bacillus subtilis from the leaf

\begin{tabular}{lccc}
\hline $\begin{array}{l}\text { Bacillus } \\
\text { subtilis } \\
\left.\text { (cfu mL } \mathbf{~ L}^{-\mathbf{1}}\right)\end{array}$ & $\begin{array}{c}\text { Increasing } \\
\text { seedling height } \\
(\mathbf{c m})\end{array}$ & $\begin{array}{c}\text { Stem } \\
\text { diameter } \\
(\mathbf{c m})\end{array}$ & $\begin{array}{c}\text { Root volume } \\
\left(\mathbf{m}^{\mathbf{3}}\right)\end{array}$ \\
\hline No B. subtilis & $38.25 \pm 6.88 \mathrm{a}$ & $2.20 \pm 0.36 \mathrm{a}$ & $69.13 \pm 3.84 \mathrm{a}$ \\
$10^{11}$ & $39.38 \pm 2.25 \mathrm{a}$ & $2.16 \pm 0.31 \mathrm{a}$ & $72.25 \pm 14.50 \mathrm{a}$ \\
$10^{12}$ & $39.88 \pm 4.13 \mathrm{a}$ & $1.84 \pm 0.25 \mathrm{a}$ & $69.13 \pm 13.73 \mathrm{a}$ \\
$10^{13}$ & $40.13 \pm 4.02 \mathrm{a}$ & $2.44 \pm 0.35 \mathrm{a}$ & $87.87 \pm 17.67 \mathrm{a}$ \\
\hline
\end{tabular}

Note: The average followed by the same lowercase letters indicates no significance according to HSD at a 5\% level

Table 2. IAA assay produced by endophytic Bacillus subtilis in vitro

\begin{tabular}{lcccc}
\hline \multirow{2}{*}{$\begin{array}{c}\text { Isolates of } \\
\text { Bacillus subtilis }\end{array}$} & \multicolumn{2}{c}{ Color indicator } & \multicolumn{2}{c}{ IAA production concentration } \\
\cline { 2 - 5 } & $\begin{array}{c}\text { Without } \\
\text { tryptophan }\end{array}$ & $\begin{array}{c}\text { Enriched with } \\
\text { tryptophan }\end{array}$ & $\begin{array}{c}\text { Without } \\
\text { tryptophan (ppm) }\end{array}$ & $\begin{array}{c}\text { Enriched } \\
\text { with tryptophan (ppm) }\end{array}$ \\
\hline BR2 & Yellow & Pink & 122 & 343 \\
BS2 & Yellow & Transparent pink & 118 & 282 \\
BM2 & Pink & Transparent pink & 124 & 132 \\
BL2 & Pink & Transparent pink & 128 & 135 \\
BR3 & Yellow & Yellow & 117 & 218 \\
BS3 & Transparent pink & Yellow & 116 & 118 \\
BM3 & Yellow & Transparent pink & 127 & 240 \\
BL3 & Transparent pink & Transparent pink & 136 & 231 \\
\hline
\end{tabular}


Table 2 shows that the isolates of endophytic Bacillus from roots, stems, bunches, and leaves produce IAA characterized by the formation of pink to transparent pink color. The highest IAA concentration is found in endophytic Bacillus from a leaf (BL2) with the IAA product concentration of 134 ppm with tryptophan enrichment and the isolate of Bacillus from roots (BR2) with the IAA product concentration of $343 \mathrm{ppm}$ without tryptophan enrichment.

Statistically, Table 3 indicates that the inoculation of $B$. subtilis and with no inoculation is not significantly differenced in the seedling height, stem diameter, and root volume. Over all, however, it is leading that B. subtilis inoculation increases the growth of oil palm seedlings. Inoculation with density of $10^{13} \mathrm{cfu} \mathrm{mL}^{-1}$ displays the highest increase of the seedling height, the stem diameter, and the root volume compared to the other treatment.

\section{Discussion \\ Incubation period, disease intensity and salicylic acid concentration}

The application of $B$. subtilis with the inoculum density of $10^{11} \mathrm{cfu} \mathrm{mL}^{-1}$ and $10^{10} \mathrm{cfu} \mathrm{mL}^{-1}$, as shown on Table 1 , has a noticeable difference from the application of $B$. subtilis with inoculum density of $10^{13} \mathrm{cfu} \mathrm{mL}^{-1}$ and without B. subtilis on the symptoms occurrences and $G$. boninense attack intensity on oil palm seedlings in the early seeding process. It is presumably caused by the greater number of B. subtilis population so that it can colonize the rooting of oil palm seedlings leading to the reason why the oil palm seedlings do not show any symptoms on the disease intensity $0.0 \%$ after 110 days of the Ganoderma inoculation. No symptoms appear after 110 days of Ganoderma inoculation and giving Bacillus indicated that the elicitor had a role in the occurrence of the affected resistance mechanism. According to Agrios (1997), impact resistance is a mechanism that normally functions to limit the growth and spread of pathogens. The effectiveness of this mechanism is enhanced by primary infections and inducing agents (biotic or abiotic) in the form of pathogenic, non-pathogenic microbes, microbial metabolites, plant extracts or synthetic compounds such as salicylic acid. Meanwhile, in the density of $10^{13} \mathrm{cfu} \mathrm{mL}^{-1}$, the initial symptoms occur in 96 days after the inoculation of $G$. boninense the disease intensity of $6.25 \%$. It is presumed that the oil palm seedling resistance toward the Ganoderma attack on the root has been colonized by endophytic Bacillus which will produce antimicrobial compounds to protect the seedlings rooting from the Ganoderma attack. Endophytic Bacillus has the ability to penetrate into the vascular system of plants so it can inhibit the penetration of $G$. boninense into the vascular system of oil palm. The ability of Bacillus to compete in the vascular system can limit Ganoderma to gain nutrients and space during proliferation so that oil palm seedlings are resistant to Ganoderma attacks (Alexander and Phin 2014). B. subtilis BR2 isolate can suppress the growth of Ganoderma sp. with growth inhibition around $78-97 \%$ in vitro (Rustam 2016).
The Bacillus inoculation with a density of $10^{11} \mathrm{cfu} \mathrm{mL}^{-1}$ and $10^{12} \mathrm{cfu} \mathrm{mL}^{-1}$ is the best compared to the concentration of $10^{13} \mathrm{cfu} \mathrm{mL}^{-1}$. The higher concentration leads to lower hampering ability. The declining of the hampering ability is presumably because of the declining of population as explained in the bacterial growth curve, the decreasing nutrition amount, and the factors contained in microbes, which trigger the growth activity to reach the maximum point and then reduce the microbe population due to cell autolysis and cell energy reduction (Lay and Hastowo 1992). A similar study was found in the research conducted by Handiyanti (2010) which suggested that the inoculation of $P$. fluorescent (Pf10) in a great number leads to the reduced capability of triggering the symptoms to have occurred at the inoculated point.

In the case of the treatment with no $B$. subtilis, the initial symptoms occur faster. It is presumably because by having no endophytic B. subtilis, it is easier for Ganoderma to infect oil palm seedlings compared to other treatments. Stein (2005) suggests that Bacillus sp. produces peptide compounds known as antifungals such as Fengycin and bacillomycin. Suryadi et al. (2015) also states that Bacillus cereus 11UJ producing 3 compounds that were 9,19cyclolanostan-3-ol, asetat, (3.beta.)- (CAS) cycloartanyl acetate; 4- (2', 2'-dimethyl-6'-methyliden-1'-cyclohexyliden)-3-methyl-2-butanone and stigmast-5-en3-ol. Oleat is presumed to be potential in inhibiting the growth of Rhizoctonia solani and Pyricularia oryzae. Besides, Saputra (2015) also discovered that Bacillus licheniformis isolate Ba-1 has a good ability to inhibit Ralstonia solanacearum on tomatoes.

In Table 1 the salicylic acid concentration was seen to be high in the concentration of endophytic Bacillus $10^{9} \mathrm{cfu}$ $\mathrm{mL}^{-1}$, which is $0.38 \%$. Increased accumulation of salicylic acid at concentrations of $10^{11} \mathrm{cfu} 1$ indicates that oil palm seedlings have begun to be responsive to activating the mechanism of biochemical resistance to Ganoderma attack. This is in line with the idea of Benhamou (1996) stating that Bacillus sp. can induce the physical resistance by thickening the cell walls or by increasing the phytoalexin compounds chemically that can provide resistance to pathogenic attacks which cause diseases in plants. While in the case of without endophytic Bacillus treatment, it is considered that the systemic resistance occurs due to the salicylic acid accumulation which increases in the plant. The secondary metabolite activities including the content of phenols and salicylic acid is an indicator that systemic resistance is taking place inside plants (Wijayanti et al. 2017).

In addition to impacting the concentration of salicylic acid compounds formed, endophytic B. subtilis. with the density of $10^{11} \mathrm{cfu} \mathrm{\textrm {mL } ^ { - 1 }}$ also accelerated the formation process of salicylic acid in the plant. Compared to the other treatments, the high concentration level of salicylic acid in the leaf extract from oil palm inoculated by endophytic $B$. subtilis. with density of $10^{11} \mathrm{cfu} \mathrm{mL}^{-1}$ is because of the activation of plants' resistance system which causes the Ganoderma sp. to attack become obstructed and the disease intensity becomes lower. Lusiyantri (2011) states that the salicylic acid resulted in the oil palm seeds is a cause of 
pathogenic fungi invasion so that the seeds' reaction is to form a resistance compound. This is supported by the statement of Edgar et al. (2006) that salicylic acid gives essential signals in the resistance mechanism and microorganism hampering process.

Bacillus subtilis as a growth promoting bacteria on oil palm seedlings

Based on the observation result, all Bacillus isolates could produce IAA. Based on Lestari et al. (2015), the IAA reaction is indicated with a color change from reddish yellow to pink. Higher color density means higher IAA content level. The highest IAA is produced by BR2 isolates that used in this study (Table 1 and 3) which are isolated from the rooting after tryptophan was added. It was the highest since tryptophan is a precursor in IAA formation by bacteria. Tanjung et al. (2015) stated that the IAA formation is due to the addition of tryptophan as the precursor. This statement was strengthened by the statement of Kholida et al. (2015) that bacteria synthesize IAA due to the presence of tryptophan precursor compounds in several lines i.e. indole-3-pyruvate (IpyA), indole-3-acetamide (IAM), tryptamine (TAM), indole-3acetonitrile (IAN) and Trp side chain oxidase (TSCO).

The bacterial suspension test result of B. subtilis. to oil palm seedlings did not show any noticeable difference in the seed height, stem diameter and root volume for the noninoculation. It is presumed that the growth of the oil palm seedlings is slower in responding to its reaction. In the experiment done by Puspita et al. (2018), the same application on cocoa seedlings shows different results i.e. the endophytic Bacillus from the roots, stems, bunch, and the leaf tissues contain IAA hormones with a concentration interval of 118-343 ppm which can increase the growth of cocoa seedlings.

The inoculation of $B$. subtilis at $10^{13} \mathrm{cfu} \mathrm{mL}^{-1}$ resulted in the highest seedling height and root volume compared to the other density and with no $B$. subtilis. It is likely because the treatment of inoculation of B. subtilis $10^{13} \mathrm{cfu} \mathrm{mL}^{-1}$ in the oil palm seedling does not show any symptoms of infection $G$. boninense so that the physiological process of the oil palm seedlings goes normally, resulting in a smooth process of photosynthesis. Therefore, it can increase the growth of the oil palm seedlings. Puspita et al. (2013) state that the produced IAA functions as the plant growthpromoter by stimulating cell division, cell enlargement and optimal absorption of water and nutrients that affect plant growth. The result shows that endophytic Bacillus of the leaves at a density of $10^{11} \mathrm{cfu} \mathrm{mL}^{-1}$ could increase the seedling height, the number of leaves and the area of cocoa leaf (Puspita et al. 2018). The Bacillus species used as a biological agent may bring a direct impact on the plants grow through the growth hormone synthesis (Amer and Utkhede 2007). The strain of B. subtilis is capable of improving plants growth through phytohormones (Auxin, cytokine, gibberellin, and ethylene) and enzymes (e.g. 1aminocyclopropane-1-carboxylic acid (ACC) deaminase) as well as a nutrient mineralization promoter such as phosphate, potassium, and zinc solvents, Nitrogen (nitrogen fixation), and the improvement of the roots ability for absorption. Phytohormone produced by $B$. subtilis has a key role in promoting growth and ethylene (Singh et al. 2008). Indole-3-acetic acid (IAA) is the original phytohormone auxin which functions as a signal molecule in the regulation of plant's development (Ashrafuzzaman et al. 2009).

Besides, the existence of IAA produced by endophytic B. subtilis may increase the oil palm seedlings resistance from G. boninense attacks. According to Kremer (2006), IAA hormones can affect plants resistance toward pathogenic attacks. This current study shows that the inoculation of B. subtilis can induce oil palm seedling resistance to infection of $G$. boninense with the increasing levels of salicylic acid and IAA hormones.

\section{ACKNOWLEDGEMENTS}

The authors would like to thank the Department of Agrotechnology, Faculty of Agriculture, Universitas Riau, Pekanbaru, Indonesia for the support and the resources provided for this research.

\section{REFERENCES}

Abdul Razak J, Ahmad H, Ramdhan K, Idris AS, Abdul Rahim S, Aminul R, Fauzi I. 2004. Mechanical Trunk Injection for Control of Ganoderma MPOB Information Series. MPOB TT No. 215. Malaysian Palm Oil Board, Ministry of Plantation Industries and Commodities Malaysia, Kuala Lumpur.

Agrios GN. 1997. Control of Plant Diseases. In: Plant Pathology, 4th ed, Academic Press, San Diego

Alexander A, Phin CK.. 2014. Combination of Biological Agents in Suppressing Colonization of Ganoderma boninense of Basal Stem rot. Amer-Eur J Sustain Agric 8 (7): 1-7.

Ashrafuzzaman M, Hossen FA, Ismail MR, Hoque MA, Islam MZ, Shahidullah SM, Meon S. 2009. Efficiency of plant growthpromoting rhizobacteria (PGPR) for the enhancement of rice growth. Afr J Biotechnol 8: 1247-1252

Benhamou N. 1996. Elicitor-induced plant defense pathways. Trends Plant Sci 1 (7): 233-240.

CIBA-GEIGY. 1997. Field Trial Manual Basle. CIBA-GEIGY, San Fransisco, CA.

Handiyanti M. 2010. Potential of Bacillus sp. and Pseudomonas fluorescens as a controlling agent for soft bacterial rot (Erwinia carotovora) in Phalaenopsis orchids. [Thesis]. Bogor Agricultural University, Bogor. [Indonesian]

Keen NT, Sims JJ, Erwin DC, Rice E, Partridge JE. 1971. 6ahydroxyphaseollin: an antifungal chemical induced in soybean hypocotyls by Phytophthora megasperma var. sojae. Pltytopathology 61: 1084-1089.

Kremer RJ. 2006.The role alleophatic bacteria in weed management. In: Inderjit MK. (eds.). Allelochemicals: Biological Control of Plant Pathogens and Diseases. Disease Management of Fruits and Vegetables, Vol. 2. Springer, Dordrecht.

Lay BW, Hastowo. 1992. Microbiologi Rajawali Press. Jakarta. [Indonesian]

Lusiyantri. 2011. Resistance Test for Resilience with Bacillus sp. and Fitrat Culture to the Attack of Ganoderma boninense and Growth of Palm Oil Seedlings in Early Nursery. [Hon. Thesis]. Faculty of Agriculture, University of Riau, Pekanbaru. [Indonesian]

Nasahi C, Widiantini F, Yulia E, Meliansyah R, Rasisetyo P. 2016. Isolation and detection of potential endophytic actinobacteria in controlling stem rot disease in oil palm plants (Ganoderma boninense Pat.). In: Joko T (eds). Proceedings of the National Seminar on Plant Disease Control Environmentally Friendly II, 2016. Indonesian Phytopathol Association, Yogyakarta. [Indonesian] 
Nonaka F, Matsuzaki M. 1976. Production of Hydroxyphaseolin in soybean leaves infected with the leaf blight bacterium Xanthomonas phaseoli var. sojae and its antifungal action. Bull Fac Agric Saga Univ 40: 1-10.

Prasetyo AE, Susanto A, Utomo C. 2008. Avoidan methods of palm oil basal stem rot (Ganoderma boninense) with large planting hole system. Jurnal Pendidikan dan Kajian Seni 16 (2): 77-86. [Indonesian]

Priwiratama H, Prasetyo AE, Susanto A.. 2014. Cultural practices for management of basal stem rot disease of oil palm. Jurnal Fitopatologi Indonesia 10 (1): 1-7. DOI: 10.14692/jfi.10.1.1. [Indonesian]

Puspita F, Saputra S.I, Merini J. 2018. Various concentration of endophytic Bacillus sp. to improve growth of cocoa (Theobroma cacao L.) seedling. J. Agron. Indonesia 46 (3): 322-327. DOI: 10.24831/jai.v46i3.16342.

Puspita F, Zul D, Khoiri MA. 2013. Proceedings of the National Seminar on the Role of Technology and Agricultural Institutions in Realizing Resilient and Sustainable Agricultural Development, Riau University, Pekanbaru. [Indonesian]

Rustam. 2016. Antifungal study of Bacillus subtilis BR2 on Ganoderma $\mathrm{sp}$, the cause of basal stem rot disease in oil palm plants. Asian J Eng Technol 4 (3): 54-58.

Saputra R, Arwiyanto T, Wibowo A. 2015. Test antagonistic activity of some isolates Bacillus spp. against bacterial wilt (Ralstonia solanacearum) in some tomato varieties and their identification. Pros
Sem Nas Masy Biodiv Indon 1 (5): 1116-1122. DOI: 10.13057/psnmbi/m010525. [Indonesian]

Setyawan B, Berlian I, Prasetyo NE. 2016. Exploration of endophytic bacteria and its potency to inhibit white root fungi (Rigidoporus microporus). Jurnal Penelitian Karet 34 (2): 175 - 188. [Indonesian]

Singh N, Pandey P, Dubey RC, Maheshwari DK (2008) Biological control of root rot fungus Macrophomina phaseolina and growth enhancement of Pinus roxburghii (Sarg.) by rhizosphere competent Bacillus subtilis BN1. J. Microb Biotechnol 24: 1669-1679

Stein T. 2005. Bacillus subtilis antibiotics: Structures, Syntheses and Specific Functions. J Mol Microbiol 56 (4): 1-5.

Sudantha IM, Sridanti NK, Suheri H. 1993. Use of agricultural waste compost for Fusarium wilt disease control in tomato plants. pp. 261268. Risalah KongresNasional XII dan Seminar Ilmiah PFI, Yogyakarta. [Indonesian]

Wijayanti KS, Rahardjo BT, Himawan T. 2017. The effect of rhizobacteria in increasing the content of salicylic acid and plant phenol total against emphasis to nematode root. Buletin Tanaman Tembakau, Serat dan Minyak Industri 2: 53-62. [Indonesian]

Zhao L, Y Xu, X.H, Lai, C. Shan, Z. Deng, Y. Ji.2015. Screening and characterization of endophytic Bacillus and PaeniBacillus strains from medicinal plant Lonicera japonica for use as potential plant growth promoters. Braz J Microbiol 46: 4. DOI: 10.1590/S1517838246420140024 